\title{
New Polychaete Records from Seagrass Beds at Minicoy Island, Lakshadweep, India
}

\author{
Dalia Susan V, NGK Pillai*, and P Satheeshkumar \\ Central Marine Fisheries Research Institute, Kochi-682018, Kerala, India
}

Received 23 August 2011; Revised 20 November 2011; Accepted 6 December 2011

(c) KSO, KORDI and Springer 2011

\begin{abstract}
Species composition, distribution and taxonomic description of polychaete fauna in the seagrass beds of the Minicoy lagoon, Lakshadweep, India were studied during 1999 - 2001. In 4 stations, 27 species of polychaetes belonging to 14 genera were identified. Of these 27 species, 10 species of polychaetes, belonging to 8 genera under 6 families, comprise new distributional records from Minicoy Island, and the descriptions of these species are provided. Among these, Glycera lancadivae, G. tesselata, and Eurythoe matthaii are found to be the most dominant species.
\end{abstract}

Keywords - polychaetes, species, distribution, seagrass

\section{Introduction}

The Lakshadweep group of islands, located off the Southwest coast of India in the Arabian Sea, consists of 36 islands covering an area of $32 \mathrm{~km}^{2}$. Seagrasses are colonial marine flowering plants that occur in shallow soft-sediment habitats along the shores of bays and estuaries throughout the world. They are of paramount importance in the coastal environment because they generally form dense beds that may cover extensive areas (Omena et al. 2004). From the Indian coast, some information is available on the polychaete fauna of seagrass communities in the Arabian Sea (Ansari 1984; Ansari et al. 1990, 1991). Benthic polychaetes are important indicators of health of the habitat and play a critical role as a major source of energy to economically and ecologically important demersal fishes.

Previous community studies on polychaetes in Minicoy Island were limited to a study of benthic macro and meiofauna

*Corresponding author. E-mail: gopalji2@rediffmail.com of the seagrass bed by Ansari (1984) during cruise No. 104 undertaken by R.V. Gaveshni. The study was based on a one-time collection up to the level of major benthic groups, and no detailed information is available on the benthic polychaete species of this region. Ansari et al. (1991) conducted studies on seagrass habitat complexity and macro invertebrate abundance in Lakshadweep coral regions. The objective of the study was to contribute to the knowledge of polychaete distribution from seagrass beds present along the Indian coast. The present study reports 11 species of polychaete fauna from seagrass beds in a tropical lagoon at Minicoy, Lakshadweep. Taxonomic accounts, distribution, and species descriptions are detailed here.

\section{Materials and Methods}

Minicoy Island, located at $08^{\circ} 17^{\prime} \mathrm{N}$ and $73^{\circ} 04^{\prime} \mathrm{E}$, is the southernmost island in the Lakshadweep group with a land area of $4.4 \mathrm{~km}^{2}$ and length of $9.5 \mathrm{~km}$. The tidal amplitude is approximately $1.75 \mathrm{~m}$ (Fig. 1). Dense seagrass vegetation is present at the southern and northern sides of the island. The study was conducted from September 1999 to August 2001. Four stations, located in the intertidal zone and occupied by seagrass, were selected. Station 1 was located on the southern side of the island and mainly consisted of a luxuriant growth of seagrass (Thalassia sp.). Station 2, occupied by a Thalassia-Halophila bed, was located away from the high tide mark to the lagoon side. Station 3 was located on the northwest side of the island and had only a sparse growth of seagrass (Cymodocea sp.). Station 4 had a Syringodium bed was located on the northwest side of the island, almost 200 $\mathrm{m}$ away from the high tide mark into the lagoon. 


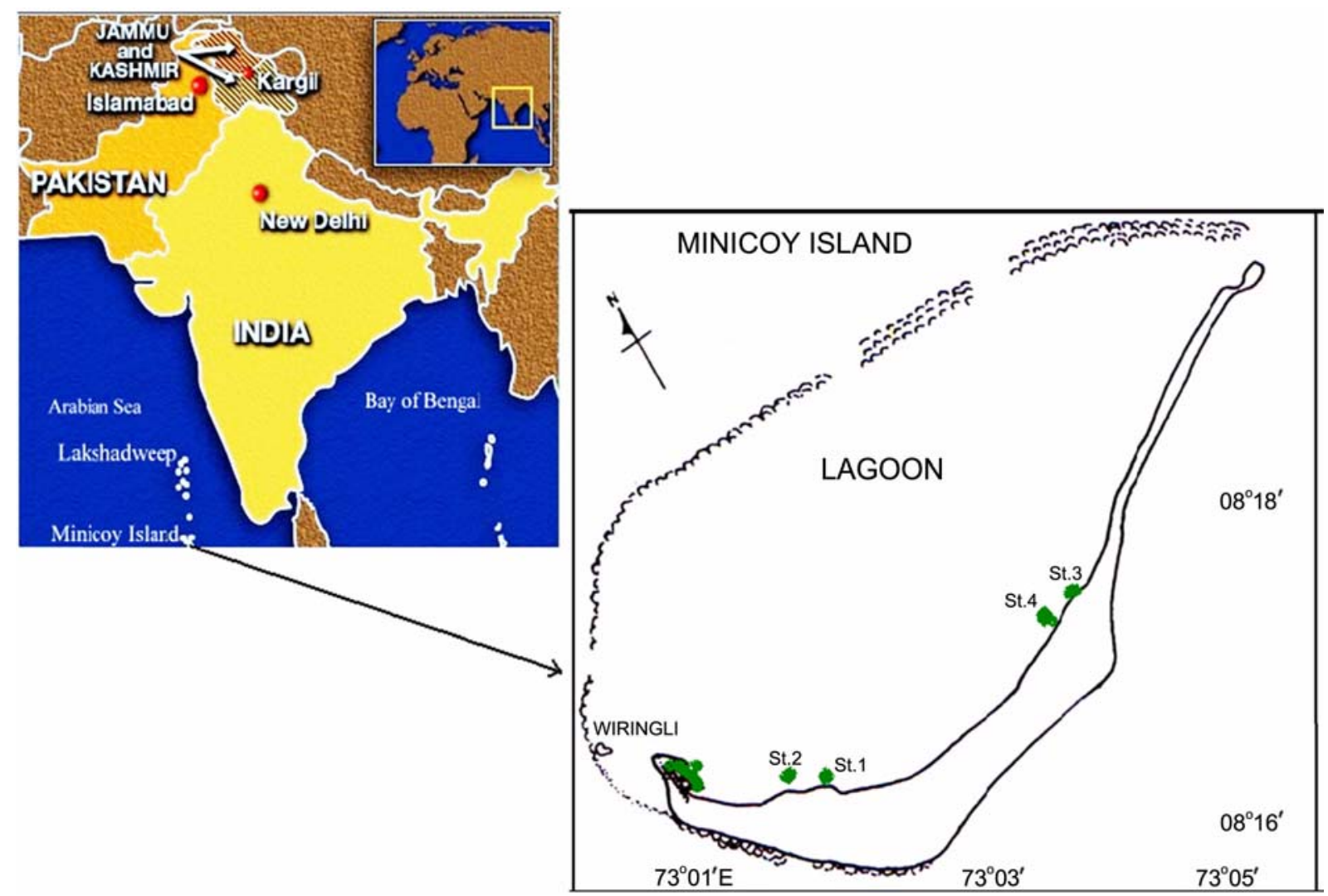

Fig. 1. Location map of Minicoy Island, Lakshadweep showing the sampling stations. St1=Station 1, Southern Thalassia bed, St2= Station 2, Southern Thalassia-Halophila bed, St3=Station 3, Northern Cymodocea bed, St4=Station 4, Northern Syringodium bed

\section{Sample collection}

Samples were collected every month with a metal quadrant of $25 \mathrm{~cm} \times 25 \mathrm{~cm}$ size, up to a depth of $15 \mathrm{~cm}$ (Ansari 1984). All samples were collected during low tide when maximum intertidal exposure prevailed. Animals were separated from the sediment by sieving through a 0.5 $\mathrm{mm}$ mesh metal sieve; material retained in the sieve was preserved in 5\% buffered formalin and species were identified using the keys suggested by Day (1967) and Fauvel (1953).

\section{Taxonomic Account}

Ceratonereis erythraeensis (Fauvel, 1918) (Fig. 2A)

Ceratonereis erythraeensis Fauvel, 1918: 505; Fauvel, 1919: 407, pl.16 fig. 26-30

Order: Phyllodocida; Williams, 1851

Family: Nereididae; Johnston, 1865

\section{Key to species}

i) Prostomium with 2 antennae, proboscis with conical paragnaths on the maxillary ring but fairly smooth basal ring.

ii) Posterior falcigers all normal and compound, proboscis with group $\mathrm{I}=0$, posterior feet with 1 or 2 enlarged simple setae formed by falcigers, with the blade fused to the shaft proboscis with group $\mathrm{I}=2-6$ points.

\section{Description of the species}

Body slender, up to $160 \mathrm{~mm}$ long, prostomium broader than long, antennae short, tentacular cirri fairly long. Paragnaths with group $\mathrm{I}=$ a group of $2-6, \mathrm{II}=$ a double row of about 10 , $\mathrm{III}=\mathrm{a}$ transverse patch about $18, \mathrm{IV}=\mathrm{a}$ wedge of $12-15$. All paragnaths are elongate cones. Anterior feet with 2 notopodial lobes and short dorsal cirrus of the same length; posterior feet similar but the lobes are more pointed. No notopodial falcigers. Neuropodial falcigers have short blades without tendons and 1 or 2 of the posterior feet are enlarged with blades fused to the shafts to form simple hooks.

Type Locality: Madagascar

Distribution: Indian Ocean, Madagascar, West Australia, Japan 


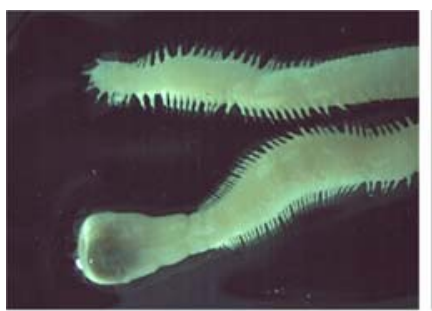

(A) Glycera lancadivae

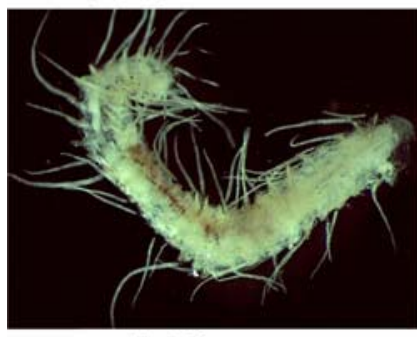

(C) Syllis cornuta

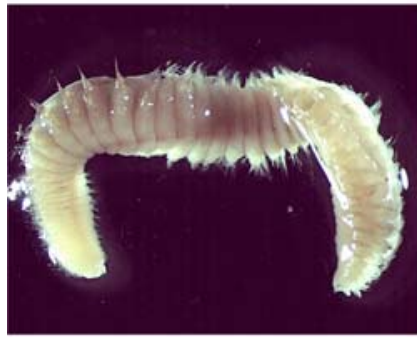

(E) Eurythoe complanata

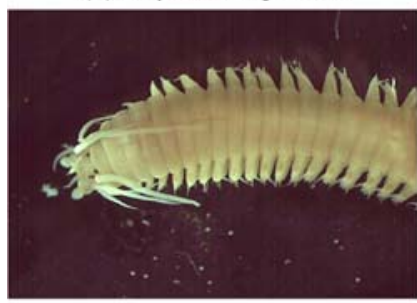

(G) Ceratonereis erythraensis

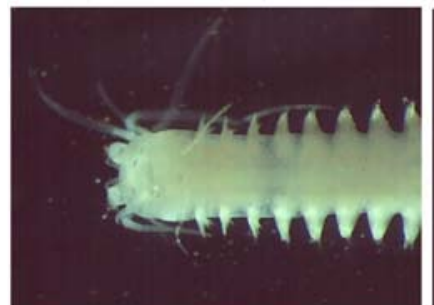

(I) Nereis kauderni

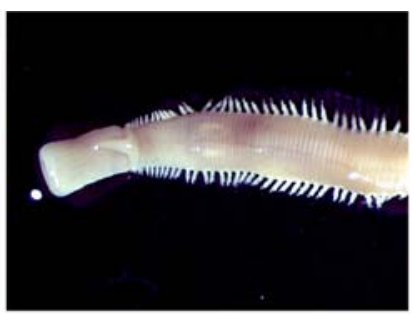

(B) Glycera tesselata

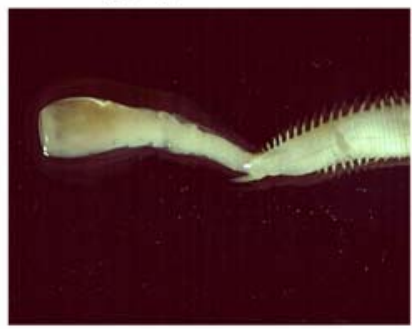

(D) Goniada maculata
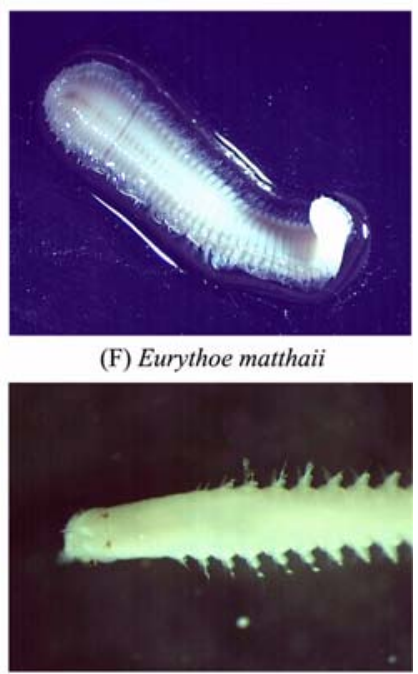

(H) Nematonereis unicornis

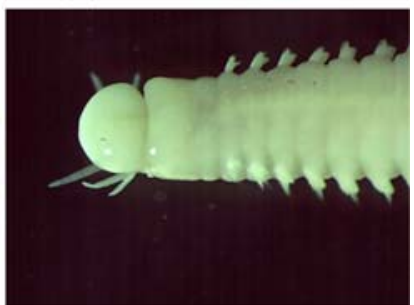

(J) Marphysa macintoshi
(F) Eurythoe matthaii

Fig. 2. New polychaete records from seagrass beds at Minicoy Lagoon, Lakshadweep, India.

Glycera lancadivae (Schmarda, 1861) (Fig. 2B)

G. lancadivae Schmarda, 1861: 95 with text figs; Fauvel, 1953, fig. 147 g-h; Day, 1962: 641

Family: Glyceridae; Grupe, 1850

\section{Key to species}

i) Body elongated with numerous segments and tapered at both ends.

ii) Proboscidial papillae conical with 15-20 rings

\section{Description of the species}

Body pale and up to $90 \mathrm{~mm}$ long, prostomium indistinctly ringed. Proboscis with slender, conical papillae having 1620 rings and a few broader forms. Jaw supports with widely divergent, unequal prongs, so deeply divided as to be almost separate. Branchiae absent, parapodia with 2 sub-equal pointed presetal lobes and a low rounded to emarginated postsetal lobe.

Type locality: Ceylon

Distribution: Madagascar, Indian Ocean

Glycera tesselata (Grube, 1863) (Fig. 2C)

Glycera tesselata Grube, 1863: 41; Fauvel, 1923: 387, fig. 152 a-c

Family: Glyceridae; Grupe, 1850

\section{Key to species}

i) Papillae of the proboscis long and slender. Nonretractile branchiae arising from the dorsal edges of the parapodia, retractile branchiae arising from the anterior faces of parapodia.

ii) Notopodial capillary chaetae in a single bundle. Neuropodial chaetae are compound, in 2 bundles.

\section{Description of the species}

Body small, 15-35 mm long with 70-100 segments. Prostomium quite long and slender composed of ca. 8 (1215) rings, with palps and antennae forming a cross at the tip. Supports of the jaws with two long dagger-like processes. Mid-body segments biannulate, 2 prechaetal lamellae long and pointed, notopodial chaetae shorter than the neuropodial chaetae. Postchaetal lamellae paired and rounded. Dorsal cirri on body wall, ovoid; ventral cirri triangular. No branchiae, and gills absent. Short pharynx with papillae of 2 kinds: tall and slim, and broad and conical.

Type locality: Mediterranean Sea

Distribution: Atlantic from Scotland to Morocco; North Carolina; Mediterranean Sea; Red Sea; Tropical Indian Ocean; Japan; Western Canada to Southern California.

Goniada maculata (Oersted, 1843) (Fig. 2D)

Goniada maculata Oersted, 1843: 33; Fauvel, 1923: 392, 
fig. 154 a-g; Hartman, 1950; 20, pl. 1 figs. 7-8

Family: Goniadidae; Kinberg, 1866

\section{Key to species}

i) Anterior 27-42 parapodia uniramous with 1 finger-like prechaetal lamella until segment 18-30, followed by uniramous segments with 2 prechaetal lamellae. Dorsal and ventral cirri finger-like.

ii) Macrognaths with 5-8 teeth. Upper half of proboscis with 4 small Y-shaped micrognaths, lower half with 3 somewhat bigger, X-shaped ones. 7-11 chevrons on each side.

\section{Description of the species}

Body anteriorly cylindrical, posteriorly more flattened. Prostomium conical composed of 10 rings, with palps and antennae forming a cross at the tip. Two small eyes on the basal ring, proboscis with 7-11 chevrons and densely covered with low cordate papillae. Mouth with a dorsal arc of 4 micrognaths, a ventral arc of 3 micrognaths and a pair of ventrolateral macrognaths with 4-8 teeth. The anterior region consists of 35-40 uniramous segments. Each anterior foot has blade-shaped dorsal cirrus, a setigerous lobe in which the pre- and post-setal lobes are fused for the first 18 setigers and blade-like ventral cirrus. From setiger 19, a second digitiform presetal lobe may be distinguished from the smaller postsetal lip, and finally from setiger $31-37,2$ presetal and 1 postsetal lips may be seen. Ventral cirri digitiform; the feet of the more flattened posterior biramous region have a notopodium with a dorsal cirrus and an inferior setigerous lobe bearing a bundle of capillary notosetae. The neuropodium has 2 finger-like presetal lobes and a single shorter, bluntly triangular postsetal lobe, a digitiform cirrus, and a fan of spinigerous compound setae.

Type locality: Denmark

Distribution: Arctic; North Atlantic from Norway to the English Channel and North Carolina; North Pacific; Persian Gulf.

Syllis cornuta (Rathke, 1843) (Fig. 2E)

Syllis cornuta Rathke, 1843: 194; Syllis (Ehlersia) cornuta Fauvel, 1923: 267, fig. $100 \mathrm{~g}-\mathrm{i}$

Family: Syllidae; Grube, 1850

\section{Key to species}

i) Three antennae; 2 pairs of tentacular cirri, all articulated. Eversible pharynx with a single tooth. ii) Parapodia with pseudo-composite and simple setae in addition to composite ones. Dorsal cirri short and jointed throughout secondary tooth to become larger than the terminal one.

\section{Description of the species}

Body long and slender, prostomium semicircular with 4 eyes and 2 ocular specks, palps large. Pharynx long with an anterior foot, proventriculus with 30-35 rows of points. Dorsal cirri short with 10-18 joints, which are always clearly marked. One to 3 superior setae with very long blades, and about 6 with normal bidentate blades with slender secondary tooth.

Type locality: Norway

Distribution: Atlantic from Greenland to Georgia and Scotland to Antarctic; Tropical Indian Ocean

Eurythoe complanata (Pallas, 1766) (Fig. 2F)

Aphrodite complanata Pallas, 1766: 109; E. complanata Fauvel, 1753: 83, fig. 38 b-m.

Order: Amphinomida

Family: Amphinomidae; Savigny, 1818

\section{Key to species}

i) Caruncle longer than wide with a large, smooth, and sinuous median ridge nearly covering the narrow lateral parts.

ii) A large species reaching $140 \mathrm{~mm}$; spurred and forked setae smooth.

\section{Description of the species}

Body elongate and flattened, color grayish green. Caruncle elongated with a flat keel, and attached as far back as setiger 3 but overlaps setiger 4 . Branchiae from setiger 2 onwards. Notosetae of 3 types: (a) smooth pointed setae, (b) harpoon-setae with recurved serrations on 1 side, (c) fin setae with small spur or step and a long, slender with very faint serrations. Neurosetae of the following types: (a) forked setae with smooth prongs of equal length and (b) slender setae with a small spur at the base of a long blade.

Type locality: Caribbean Sea

Distribution: All tropical seas

Eurythoe matthaii (Kindberg, 1857) (Fig. 2G)

Family: Amphinomidae; Savigny, 1818

\section{Key to species}

i) Branchiae from setiger 1, caruncle is short. 
ii) Body rectangular in cross section with 4 buccal segments.

\section{Description of the species}

Size: Length $65-110 \mathrm{~mm}$ by $5-8 \mathrm{~mm}$. Branchiae beginning on the first segment. Caruncle oval, extending over the first 2 segments and anus is terminal. Median tentacle shorter than the paired tentacles. Eyes are hidden by the anterior margin of the caruncle; anterior ones larger than the posterior. Harpoon-shaped setae well developed, reaching the length of the bifid setae.

Type locality: Indonesia

Distribution: Tropical Indian Ocean, Tropical West Africa

Nematonereis unicornis (Grupe, 1840) (Fig. 2H)

Lumbriconereis unicornis Grupe, 1840: 80; Nematonereis unicornis Fauvel, 1923: 412, fig. 162 h-n.

Order: Eunicida

Family: Eunicidae; Savigny, 1818

\section{Key to species}

i) Palps completely fused and head rounded in front, 2-4 eyes. A single antenna, maxilla with 4 pairs of toothed plates.

ii) Mandibles well developed, No tentacular cirri on the second apodous segment.

\section{Description of the species}

Body slender, 150-200 mm long, reddish anteriorly. Head ovoid, with single tapered antenna slightly shorter than prostomium, and a pair of posterior large, rounded, black eyes. Mandibles gouge-shaped. Maxilla I are falcate and maxilla $\mathrm{V}$ are mere chitinized patches, the dental formula being as follows: Maxilla $\mathrm{I}=1+1$, Maxilla $\mathrm{II}=4+5$, Maxilla III $=4+0$, Maxilla $\mathrm{IV}=4+6$. The dorsal cirri are rather longer than the setigerous lobes, which are compressed, truncate cones. Acicular setae appear about the $20^{\text {th }}$ foot and are dark in the adult and boldly bidentate. Superior setae include winged capillaries and broad comb-setae. Inferior setae and bidentate falcigers with the secondary tooth larger than the apical one.

Type Locality: Adriatic and Mediterranean Sea.

Distribution: North Atlantic to Morocco, Mediterranean Sea, Suez Canal, Tropical Indo West Pacific.

Nematonereis kauderni (Willey, 1905) (Fig. 2I)

Ceratonereis falcaria Willey, 1905: 272, pl. 4 fig. 89; Nereis kauderni Fauvel, 1921: 8, pl. 1 figs. 1-7; Nereis falcaria
Knox, 1951: 215, pl. 44 figs. 1-5

Family: Eunicidae; Savigny, 1818

\section{Key to species}

i) Notopodia falcigers present on posterior feet (Sub genus Nereis).

ii) Prostomium deeply notched between the antennae. No branchiae.

\section{Description of the species}

A small slender species up to $30 \mathrm{~mm}$, long with a pattern of broken brown bars anteriorly. Prostomium notched between the antennae; tentacular cirri short. Proboscis with group $\mathrm{I}=0, \mathrm{II}=$ a double row of about $8, \mathrm{III}=$ a scattered group of 5-10, IV as a wedge-shaped group of $6-10, \mathrm{~V}=0$, VI is a close-set cluster of 3-4, VII and VIII combined are a single row about 8 points. All paragnaths may be pale and very difficult to see. Notopodia have 2 lobes in all feet, but the superior one is always small and decreases in size posteriorly. Dorsal cirri longer than notopodial lobes, in the posterior notopodia there are 1-2 large homogomph falcigers whose blades have 2-3 large teeth.

Type Locality: Ceylon

Distribution: Indo West Pacific; New Zealand

Marphysa macintoshi (Crossland, 1903) (Fig. 2J)

Marphysa macintoshi Crossland, 1903; 137, pl. 14, figs. 3-6, fig. 12; Day, 1962: 643

Family: Eunicidae; Savigny, 1818

\section{Key to species}

i) Branchiae absent; acicular setae unidentate; body rounded in section.

ii) Dorsal side not covered with felt, chaetae, membranes, or scales.

\section{Description of the species}

Body >200 mm long, slender, rounded, or somewhat flattened. Palps partially fused and the anterior margin of the head is not obviously blobbed. Antennae smooth, about as long as the prostomium. Maxillary formula: $\mathrm{MX} \mathrm{I}=1+1$, MX II=7+1, MX III=7+0, MX IV=3+8, MX V; all these are chitinized areas without teeth. Eyes not defined and mandibles normal. Gills appear on the $20^{\text {th }}-50^{\text {th }}$ foot according to size, reach a maximum of 6 filaments and gradually decrease towards the end of the body. Acicular, 
Table 1. Species composition of Polychaetes from Minicoy Island, Lakshadweep

\begin{tabular}{|c|c|c|c|c|c|}
\hline S. no & Species & Station 1 & Station 2 & Station 3 & Station 4 \\
\hline 1 & Ceratonereis erythraensis & - & + & + & + \\
\hline 2 & Eurythoe complanata & + & + & - & + \\
\hline 3 & E. matthaii & + & + & + & - \\
\hline 4 & Goniada maculata & + & + & + & + \\
\hline 5 & Glycera lancadivae & + & + & + & + \\
\hline 6 & G. tesselata & + & + & + & + \\
\hline 7 & Marphysa macintoshi & + & + & + & + \\
\hline 8 & Nematonereis unicornis & + & + & + & + \\
\hline 9 & Nereis kauderni & + & + & - & + \\
\hline 10 & Syllis cornuta & + & + & + & + \\
\hline
\end{tabular}

(+) Presence; (-) absence

bluntly pointed, and brown with pale tips; they decreases from 3 anteriorly to 1 in the middle of the body. A single brown acicular seta with a simple blunt tip; superior setae are compound with knife-shaped blades, though they are often retracted so deeply that only the blades protrude, simulating simple setae.

Type Locality: Zanzibar

Distribution: Red Sea and Tropical Indian Ocean

\section{Results and Discussion}

Altogether, 27 species of polychaetes belonging to 14 genera were identified. Of these 27 species, the 10 species described above are new distributional records from Minicoy Island (Fig. 2A-J). A maximum of 10 species were collected at station 2, followed by 9 species at stations 1 and 4 , and 8 species were recorded from station 3. The list of polychaetes collected from the study area is given in Table 1. The dominant species that were found throughout the study period were G. lancadivae at stations 1-2, G. tesselata at stations 3 and 4, and Eurythoe matthaii at station 3 .

The substratum of the seagrass bed was predominated by sand, followed by clay and silt in comparatively smaller proportions. The highest value for sand was observed in the monsoon and postmonsoon seasons (95-96\%) and slightly less in the premonsoon period $(90 \%)$. Silt percentage remained almost the same during all seasons, showing little variations. In both years, a comparatively higher percentage of clay was observed in the premonsoon season. Organic carbon content varied from 0.30 to $1.95 \%$ in the seagrass ecosystem. Polychaetes showed their maximum average monthly abundance at station $1\left(188 \mathrm{ind} . / \mathrm{m}^{2}\right)$, followed by station $3\left(112 \mathrm{ind} . / \mathrm{m}^{2}\right)$, station $4\left(108 \mathrm{ind} . / \mathrm{m}^{2}\right)$, and station 2 $\left(96\right.$ ind. $/ \mathrm{m}^{2}$ ). Among these species, the highest percentages of occurrence were shown by E. matthaii (25\%), G. tesselata (22.9\%), and G. lancadivae (18.8\%).

The polychaete density was highest at station 2 followed by stations 1,3 , and 4 . A high population density at station 2 coincided with high organic matter content compared to other stations. The low density recorded at station 4 during the southwest monsoon might be due to freshwater flow, which induced low saline conditions, which in turn affected the distribution of polychaetes. Species composition and the abundance of polychaetes were generally high during the postmonsoon season followed by the premonsoon and monsoon periods. Earlier studies on macrobenthos from the seagrass intertidal areas of Minicoy were mainly confined to the major groups of benthic organisms (Ansari, 1984). He observed that polychaetes were numerically the most abundant group contributing $60-92 \%$ of the total macrobenthic organisms and were dominated by suspension and deposit feeding forms.

Infaunal diversity of seagrass beds in world oceans is poorly documented. Arana and Diaz (2006) reported 35 species of polychaetes associated with Thalassia testudinum in the northern coastal waters of Venezuela. Pocklington and Coates (2010) reported 3 new species of polychaetes in a seagrass bed dominated by Syringodium filiforme from Bermuda. More studies on polychaete fauna of seagrass beds, especially studies based on taxonomy, need to be performed in the soil habitat of the seagrass ecosystem in various localities of India, to give a complete picture of the distribution and abundance of polychaetes. 


\section{Acknowledgements}

We thank the Central Marine Fisheries Research Institute, Kochi, Kerala, for providing infrastructure facilities.

\section{References}

Ansari ZA, Ramani P, Rivonker CU, Parulekar AH (1990) Macro and meio faunal abundance in six sandy beaches of Lakshadweep Islands. Indian J Mar Sci 19:159-164

Ansari ZA, Rivonker CU, Ramani P, Parulekar AH (1991) Seagrass habitat complexity and macroinvertebrate abundance in Lakshadweep coral reef regions, Arabian Sea. Coral Reefs 10:127-131

Ansari ZA (1984) Benthic macro and meio fauna of Seagrass (Thalassia hemprichii) bed at Minicoy, Lakshadweep. Indian
J Mar Sci 3:126-127

Arana IL, Daiz OD (2006) Polychaeta (Annelida) associated with Thalassia testudinum in the northeastern coastal waters of Venezuela. Rev Biol Trop 54(3):971-978

Day JH (1967) A monograph on the Polychaeta of South Africa. Part I. Errantia. Trustees of the British Museum (Natural History), London, $498 \mathrm{p}$

Fauvel P (1953) The fauna of India including Pakistan, Ceylon, Burma and Malaya: Annelida, Polychaeta. Indian Press, Allahabad, $507 \mathrm{p}$

Omena E, Creed JC (2004) Polychaete fauna of Seagrass beds (Halodule wrightii Ascherson) along the coast of Rio de Janeiro (Southeast Brazil). Mar Ecol 25(4):273-288

Pocklington P, Coates KA (2010) Three new species of polychaetes (Annelida: Polychaeta) from Bermuda. Proc Biol Soc Washington 123(3):220-233 